\title{
Исследование отражения диафрагмами ИК излучения в тепловизионных приборах
}

\author{
А.Р. Новоселов, П.А. Алдохин, П.П. Добровольский, А.В. Гусаченко, Б.Н. Новгородов, К.П. \\ Шатунов, С.М.Чурилов \\ Филиал ИФП СО РАН «КТИПМ», г. Новосибирск, 630090, пр-кт Академика Лаврентьева, 2/1 \\ тел. (383) 330-97-49, эл. почта: novoselov@isp.nsc.ru
}

DOI 10.34077/RCSP2021-155

Исследовано отражение инфракрасного излучения покрытиями диафрагм в фотоприёмных устройствах тепловизионных приборов: черная полимерная краска, «анодный окисел», «травлёный ковар», взвесь графита или окиси титана в криогенностойком лаке и другие. Выяснены спектры и интегральные коэффициенты отражения покрытиями диафрагм в диапазоне длин волн $2 \div 14$ мкм при углах падения излучения $15^{\circ}$ и $45^{\circ}$. Также исследованы в спектральных диапазонах $3,4 \div 4,8$ и $7,5 \div 13,5$ мкм уровни отражённого инфракрасного излучения в широком диапазоне углов от $0^{\circ}$ до $80^{\circ}$ при угле падения излучения около $15^{\circ}$.

По результатам исследований определено, что наименьший уровень отражения ИК излучения имеет покрытие из взвеси графита в криогенностойком лаке (Филиал ИФП СО РАН «КТИПМ», г. Новосибирск). Интегральные коэффициенты отражения для данного покрытия составили 3,98\% (в спектральном диапазоне $3 \div 5$ мкм) и $5,69 \%$ (в диапазоне $8 \div 12$ мкм). Интегральные коэффициенты отражения эталона черного тела - 0,46\% (в спектральном диапазоне $3 \div 5$ мкм) и $0,42 \%$ - (в диапазоне $8 \div 12$ мкм).

В настоящее время технология нанесения покрытия из взвеси графита в криогенностойком лаке применяют в ИФП СО РАН для нанесения покрытий на поверхности диафрагм фотоприёмных устройств тепловизионных приборов.

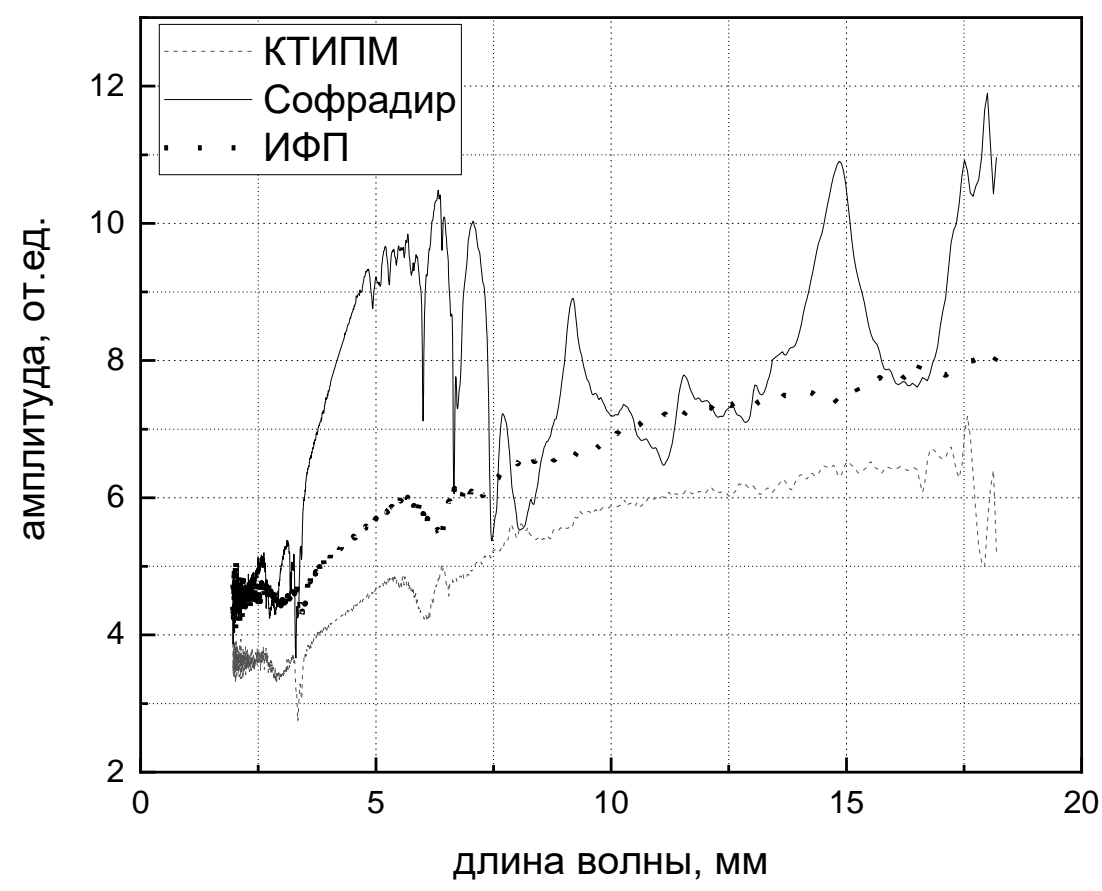

Рис. 1. Спектры отражения ИК излучения от образцов исследуемых покрытий: фирма «Софрадир» (Франция), ИФП СО РАН, Филиал ИФП СО РАН «КТИПМ». 